\title{
Performance of the Arabic Population on the Adolescent-Adult Sensory Profile: An Observational Study [Corrigendum]
}

\author{
Al-Momani F, Alghadir AH, Al-Momani MO, et al. \\ Neuropsychiatr Dis Treat. 2020;16:35-42. \\ The authors have advised that the Acknowledgment sec- \\ tion is incorrect. The correct acknowledgment is below.
}

\section{Acknowledgments}

The authors are grateful to the Deanship of Scientific Research, King Saud University for funding through Vice
Deanship of Scientific Research Chairs. This study was approved by the Deanship of Research at Jordan University of Science and Technology and Institutional Review Board of King Abdullah University Hospital, Irbid, Jordan.

The authors apologize for this error.

\section{Publish your work in this journal}

Neuropsychiatric Disease and Treatment is an international, peerreviewed journal of clinical therapeutics and pharmacology focusing on concise rapid reporting of clinical or pre-clinical studies on a range of neuropsychiatric and neurological disorders. This journal is indexed on PubMed Central, the 'PsycINFO' database and CAS, and is the official journal of The International Neuropsychiatric Association (INA). The manuscript management system is completely online and includes a very quick and fair peer-review system, which is all easy to use. Visit http://www.dovepress.com/testimonials.php to read real quotes from published authors. 